\title{
HEALTH-SAVING COMPETENCIES IN PHYSICAL EDUCATION OF STUDENTS
}

DOI: 10.36740/WLek202001128

\author{
Viktoriia I. Donchenko', Valeriy 0. Zhamardiy ${ }^{1}$,Olena M. Shkola² , Olena V. Kabatska ${ }^{3}$, Valerii H. Fomenko \\ 'UKRAINIAN MEDICAL STOMATOLOGICAL ACADEMY, POLTAVA, UKRAINE \\ ${ }^{2}$ MUNICIPAL ESTABLISHMENT «KHARKIV HUMANITARIAN PEDAGOGICAL ACADEMY» OF KHARKIV REGIONAL COUNCIL, KHARKIV, UKRAINE \\ ${ }^{3}$ V. N. KARAZIN KHARKIV NATIONAL UNIVERSITY, KHARKIV, UKRAINE
}

\begin{abstract}
The aim: The article examines the health-saving competencies of fitness technologies usage during physical education classes.

Materials and methods: Experimental work was carried out in three stages, each of which was characterized by certain goals and objectives, corresponding forms and methods of research organization. To determine the formation of each of the studied components, we used complex of valid diagnostic techniques.

Results: Implementation of the methodological system significantly influenced on general level of motivational, cognitive, activity and reflexive component formation, which significantly improved, compared with the students of control groups who studied under the traditional system. Evaluation of students' competence in applying fitness technologies showed a high efficiency of the introduced methodological system.

Conclusions: The introduced methodical system of fitness technologies application contributed to increase of the level of students' preparedness by criteria of organizational, communicative, perceptual, speech abilities to fitness technologies, general cultural level, social activity and their involvement in healthy lifestyle. At the same time, the formation of competences in fitness technology usage contributed to the creation of new content of the main components of the methodological system.
\end{abstract}

KEY WORDS: health-saving competences, criteria, levels, students, physical education, fitness technologies

Wiad Lek. 2020;73(1):145-150

\section{INTRODUCTION}

The problem of forming, preserving and strengthening the health of student youth is relevant in the contemporary dimension of being. The current society is characterized by a decline in the health of Ukrainians, which needs to be restored.The indicator of the state of human health, which is determined by the length of its life, educational level and absence of physical defects and diseases, has also noticeably decreased. Evidence of this is that in Ukraine during the period of 2010-2018, the quality of life index has decreased from 45 to 75 place and the life expectancy of average Ukrainian by 2018 is 65.1 years, whereas in 2005 it was 69.2 years, which is 10 years less than in the USA and Western Europe, 4 years less than in Poland, 2 years less than in Hungary. Since humanity is concerned about the state of its physical health, there is a need for health-saving and health-improving technologies usage not only in institutions of higher education, creating a health-saving educational environment, but also in everyday life. The use of fitness technology contributes to the formation, preservation and strengthening of students' health, teaches them a healthy lifestyle. Often fitness even provides restoration of lost functionality of the human body. Fitness and health are interconnected by cause-and-effect relationships, and health is the greatest value of a person. The refore, for a healthy and happy life, students need appropriate conditions, a special place among which belongs to the lifestyle. It is important that the latter is properly filled with motor activity, which fitness can provide. The analysis of scientific research and publications shows that the issue of fitness technologies usageduring physical education classes of students has great scientific and practical importance. Scientists emphasize that fitness technology is the most important means of improving the state of health, increasing bodyfunctional capabilities, as harmonious basis ofstudents' physical development. The search for new effective forms and methods of physical education of students is necessary $[1 ; 2 ; 3 ; 4 ; 5 ; 6]$.

\section{THE AIM}

The purpose of the article is to investigate the health-saving competence of fitness technologies usageduring physical education classes for students. Objectives of the article: 1 ) to determine the criteria for students' readiness to acquire healthcare-saving competencies; 2) to determine the level of healthcare-saving competencies formation during physical education classes of students.

\section{MATERIALS AND METHODS}

Experimental work was carried out in three stages, each of which was characterized by certain goals and objectives, corresponding forms and methods of research organi- 
zation. At the initial stage of the research (2015-2016) search-theoretical - a theoretical analysis of valeological, psychological-pedagogical and methodological literature on the problem of fitness technologies usageduring physical education classes of students was carried out, the general theoretical and methodological foundations of the research were determined; we put forward the working hypothesis and described the general ideas of the organization of research-experimental work. At the second stage (20172018) - experimental - a methodical system of fitness technologies application was developed and theoretically grounded duringphysical education classes of students, a comprehensive selection of methods for conducting the research was carried out, experimental work was carried out on approbation of the developed methodical system. The third stage (2018-2019) - generalization - the analysis of research-experimental data was carried out, the general conclusions of the study were formulated; methodical recommendations for the implementation of the developed methodical system were developed. The participants of experiment were divided into two groups (experimental and control) for further comparison of the results from introduction of the developed methodological system. To determine the formation of each of the studied components, a complex of valid diagnostic techniques was used.

\section{RESULTS AND DISCUSSION}

The whole complex of psychological and pedagogical measures related to conducting scientific researches was taken into accountduring evaluation of the effectiveness of fitness technologies methodical application during physical education classes. The identification of the effectiveness of fitness technologies methodical application during physical education classes was determined by such criteria as evidences, that show the qualitative and quantitative effectiveness of educational work and, in particular, the assessment of applied fitness technologies in the process of training student youth. In general, the effectiveness of the methodical system was evaluated according to specific indicators, which were intended to improve the quality of physical educationprocess, the level of health, physical development, physical preparedness and readiness of students to use fitness technology in their further life.

Under the efficiency of the functioning of physical education methodical system G.P. Griban, besides mastering the general tasks of physical education, considers the appearance of physical culture and health competencies as some internal, potential, hidden psychological neoplasms: knowledge, motives, preferences, interests, abilities, skills, programs of actions, systems of values, attitudes to physical culture and health activities that are manifested in the methodological competence of introduction and transfer to other members of society, in particular in the process of professional activity [7, p. 358].

It should be noted that the important condition for students' competenceformation in fitness technology usage is to ensure continuous self-education. The focus of the students on self-education and self-development in the pedagogical, general cultural and personal plan is an important indicator of teachers from physical education departments ability to focus on improving the quality of the educational process of physical education [8;9]. Formation of students' competencies regarding fitness technologies usage took place, while taking into account the practical conditionality and significance that is why they are necessary for the student in his further life. Under competencies it is considered a dynamic combination of knowledge, skills and practical abilities, ways of thinking, professional, ideological and civic qualities, moral and ethical values, which determine the ability of a person to successfully carry out professional and educational activities and is the result of training at a certain level of higher education [10, p. 28-29].

Health-saving competencies are the readiness of a graduate from educational institution to the tests that we face in public life, natural conditions; the ability to independently solve problems regarding the preservation of their own health, as well as increasement of healthy life duration through the system of modeling and predicting ways of using both physical culture means and possible changes in their own health. Physical education can be interpreted as a form of manifestation and the formation of competencies $[11 ; 12 ; 2 ; 13 ; 14 ; 15 ; 16 ; 17$ etc. $]$. The level of health-saving competencies of students in physical education is determined by readiness to use fitness technologies, which serves as an indicator of students' education in matters of maintaining their own health. The ability of students to maintain, improve and maintain their own health is a superior expression of their competence. Competencies can be considered as indicators that determine the readiness of a future specialist for further life and personal self-improvement in society and in the context of future professional activities $[7 ; 10 ; 6 ; 18]$.

The main indicator of the effectiveness of fitness technologies methodical application implementation during physical education classes is the presence of physical culture and health competencies in students. Criteria of students' readiness to master competencies during fitness technologies usage were defined motivational, cognitive, activity and reflexive components that were evaluated for high, sufficient, medium and low levels of manifestation.

Implementation of the methodological system significantly influenced the general level of formation of the motivational component, which significantly improved compared with the students of control groups (CG) who studied under the traditional system. Thus, the high level of competence formation in experimental groups (EG) was: in men $-25,53 \%$, in women $-21,13 \%$; sufficient level of competence in men $-34.04 \%$, women $-32.39 \%$; the average was $31.92 \%$ and $36.62 \%$ respectively, low level in male group was in $8.51 \%$, in female was $9.86 \%$ (Fig. 1).

In the control groups that were engaged in the traditional system of physical education, the high level of competence development of application of fitness technologies is observed only in $2.44 \%$ of males and $2.74 \%$ of females, sufficient $17.07 \%$ of males and $12,33 \%$ of females respec- 


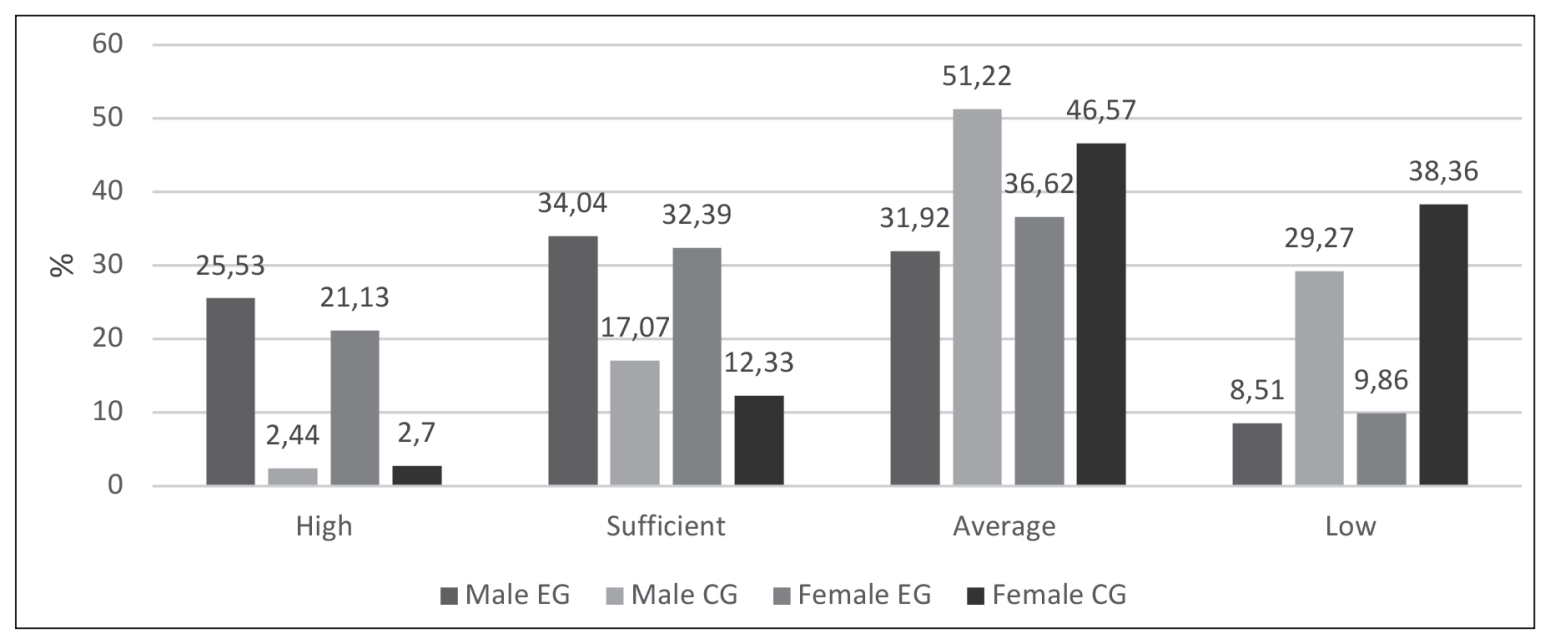

Fig. 1. Levels of training of students from experimental groups on the fitness technologies application competence based on motivational component

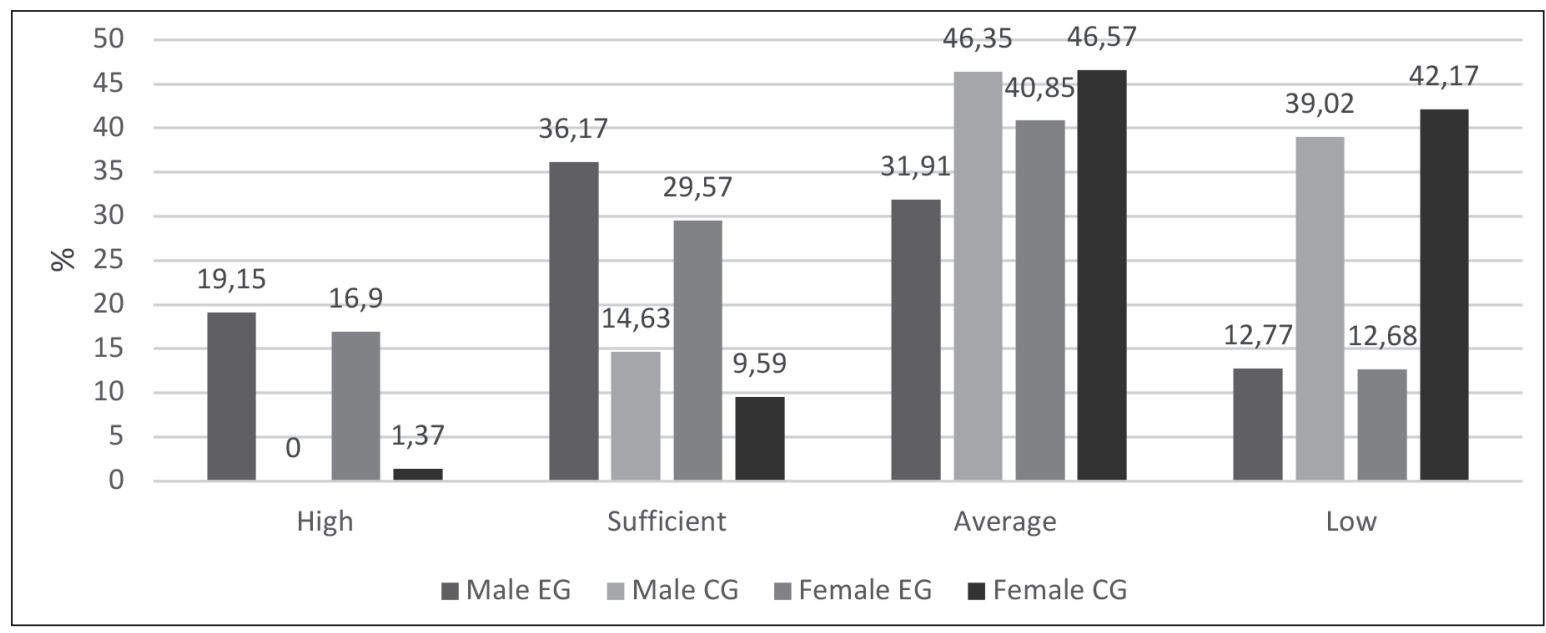

Fig. 2. Levels of training of students from experimental groups on the fitness technologies application competence based on cognitive component

tively, average in $51.22 \%$ and $46.57 \%$, low in $29.27 \%$ and $38.36 \%$. The obtained data shows a significant difference in competence formation of students from control and experimental groups, which confirms the effectiveness of the implementation of the methodological system during physical educationclasses.

Assessment of acquired competencies by students with the help of cognitive component during studying byfitness technologies methodical system application and traditional system of physical education revealed a positive dynamics regarding acquired knowledge and skills necessary for the organization and implementation of physical education and health measures for the introduction of fitness technology only in experimental groups. The formation of competencies in the cognitive component was evaluated by the presence knowledge and skills, the availability of methodical arsenal and methods, organizational skills, the ability to conduct physical culture and recreational activities, etc.

We found out that a high level of competence in the cognitive component was in $19.15 \%$ of men and $16.90 \%$ of women in experimental groups. In control groups in men, no student with a high level of competence was found, and in women only 1 student, which is $1.37 \%$.A similar tendency persists during the analysis of the competence of students with a sufficient level, in experimental groups $36.17 \%$ of men had this level and $29.57 \%$ women; in control groups $14.63 \%$ and $9.59 \%$ respectively, which significantly indicates the different levels of preparedness of students from experimental and control groups. The number of studentswith the average level of competence grows at the expense of their release from a low levelin experimental groups, while in control groups, on the contrary, their number increases due to the high and sufficient levels (Fig. 2). Significant difference is observed in low-level competence group, where significant differences between experimental groups were found: men $-12.77 \%$, women $-12.68 \%$, and control groups $-39.02 \%$ and $42.47 \%$ respectively.

The general level of competence development by cognitive component of fitness technologies application of students from experimental groups has positive dynamic after introduction of the methodical system during physical education classes. At the same time, such a form of conducting the discipline "Physical education" in general positively affects the formation of world outlook and the general cultural level of student youth. 


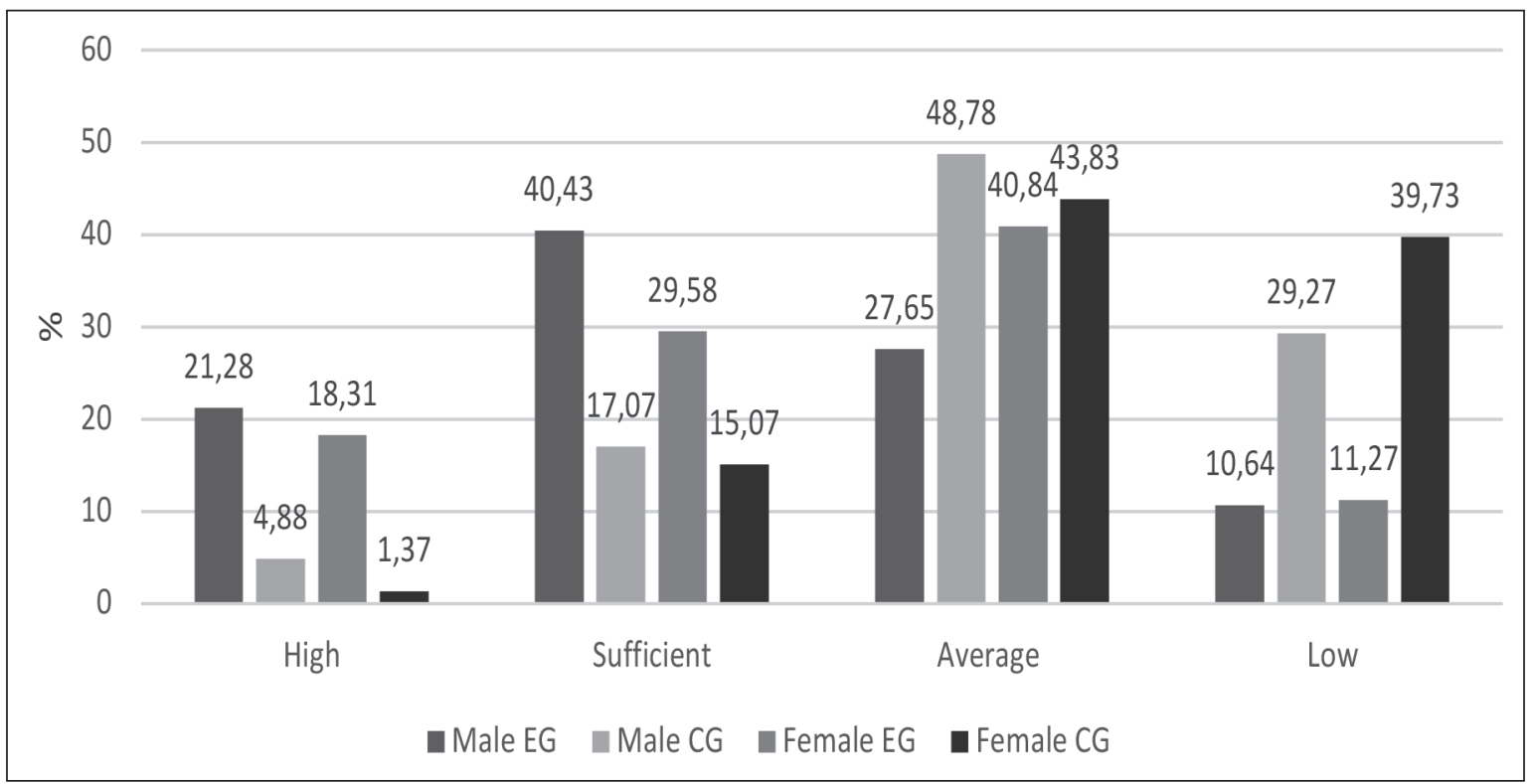

Fig. 3. Levels of training of students from experimental groups on the fitness technologies application competence based on activity component

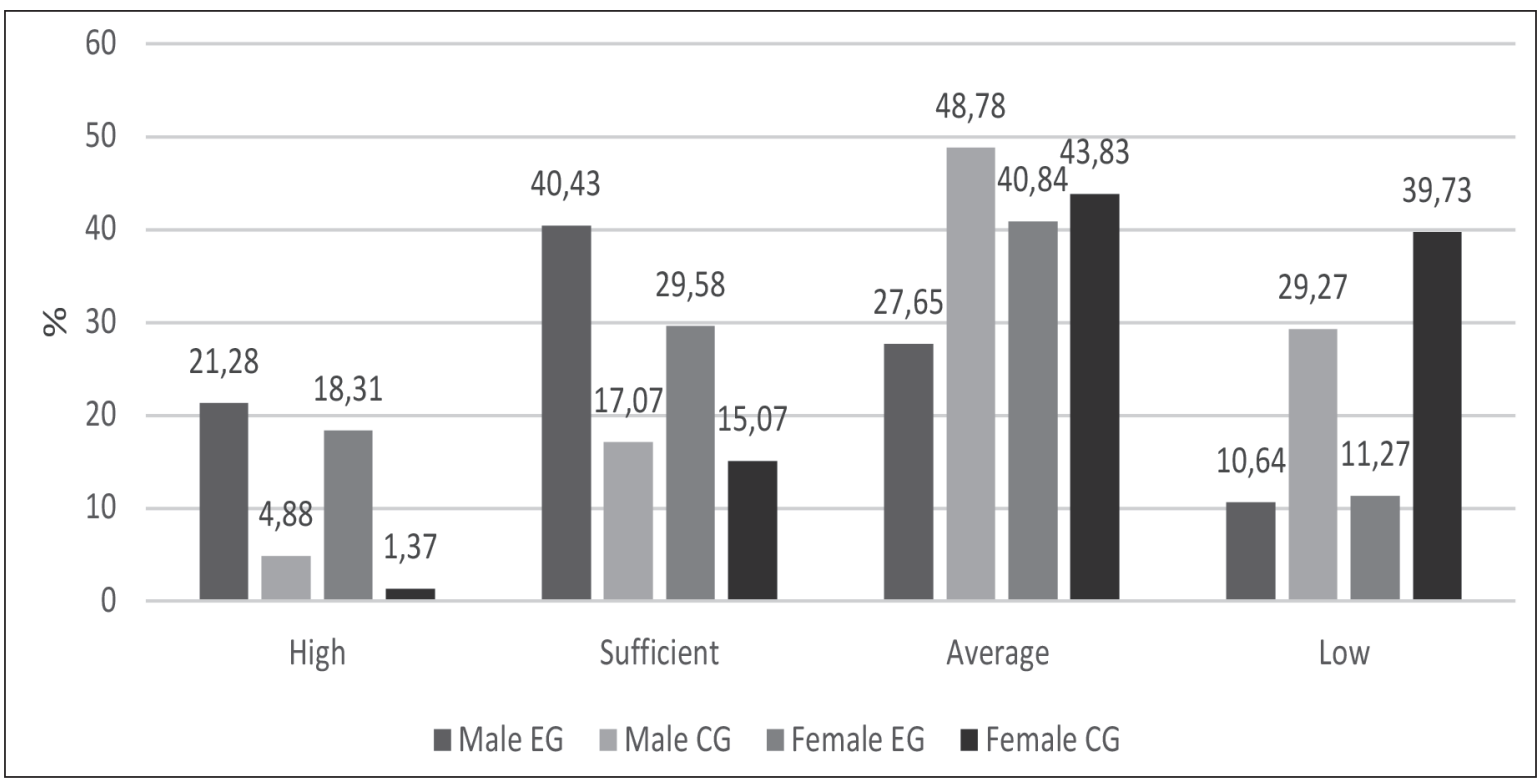

Fig. 4. Levels of training of students from experimental groups on the fitness technologies application competence based on reflexive component

Conducted control assessment after implementation of the methodological system by the activity component, confirms the improvement of the results of experimental groups with a high level of competence: EG (male) - 21.28\%, EG (female) - 18.31\%; with sufficient level: EG (male) - 40,43\%, EG (female) - 29,58\%; with an average: men $-27.65 \%$, women- $40.84 \%$; and low $-10.64 \%$ and $11.27 \%$ respectively (Fig. 3). In control groups where the methodical system of application of fitness technologies was not implemented, the indicators are much lower. With a high level of competence: CG (male)- $4.88 \%$, CG (female)- $1.37 \%$; with sufficient level: CG (male) - 17.07\%, CG (female)- $15.07 \%$; with an average: men $-48.78 \%$, women- $43.83 \%$; and low -29.27 $\%$ and $39,73 \%$ respectively.

Evaluation of students' competence in applying fitness technologies by reflexive component showed a high effi- ciency of the introduced methodological system. Thus, with a high level of competence in experimental groups were $17.02 \%$ of men and $12.68 \%$ of women and,at the same time, among students from control groups, who were engaged in the traditional system of physical education, no student was found with high level of competency. Significant discrepancies are observed when comparing students from experimental and control groups with a sufficient levelof competency, namely: among men we detected $40.42 \%$, among women $-32.39 \%$, in control groups thereweresignificantly lower number of such students $-19.51 \%$ and $16.43 \%$ (Fig. 4).Male students with an average level of competence in experimental groups are lowerbecause increase in higher levels (sufficient and high level of preparedness), in female groups, the difference is not significant. At the same time, both male and female control groups have a fairly large difference in 
number of students with a low level of competence compared with experimental groups.If in experimental groups of men, only $12.77 \%$ of students have a low level of competence, then in similar control groups such students were $29.27 \%$, women showed $-12.68 \%$ (EG) and $39.73 \%$ (CG).

Students from experimental groups have significantly better indicatorsby the level of assimilation of special knowledge, skills and abilities to exercise control over physical fitness, state of health, ability to apply in practice new fitness technologies, means and methods of development of physical qualities. The introduced methodical system of fitness technologies application contributed to increase of preparedness level of students from experimental groups according to criteria of organizational, communicative, perceptual, speech abilities to fitness technologies, general cultural level, social activity and their attraction to a healthy lifestyle. Competenciesformation in fitness technology usage contributed to the creation of new content in main components of the methodological system.

\section{CONCLUSIONS}

Thus, timely and qualitative diagnostics of the current physical state of students, the level of their physical and functional preparedness is important for fitness technologyusage in further life. Meanwhile, existing methods of estimation of these parameters today, connected mainly with conducting special motor tests, are no longer able to provide the teacher with clear and accurate information and require qualitative research, which makes it difficult to obtain operational information during the course. Another important criterion for evaluating the competencies of personal self-improvement is the ability to assess self-development, self-improvement, learn emotional self-regulation, ability to choose effective ways, means, methods, techniques and forms of motor activity in personal interests and opportunities, which should promote continuous physical perfection, adherence to a healthy way life, self-knowledge, development of physical qualities, formation of special skills and abilities. Prospects for further research are aimed at the study of theoretical and methodological principles of vocational training of physical education department teachers for physical education and health activities of students.

\section{REFERENCES}

1. Hlazyrin I. D. Osnovy dyferentsiiovanoho fizychnoho vykhovannia [Basics of differential physical education]. Cherkasy:Vidlunnia-Plius; 2003. 352 p. (Ua).

2. Dzhamalov A. R. (1970) Issledovanie effektivnosti vliyaniya razlichnykh rezhimov dvigatel'noy deyatel'nosti na fizicheskoe razvitie i fizicheskuyu podgotovlennost' studencheskoy molodezhi [Study of influence of various modes of physical activity effectiveness on the physical development and physical fitness of student youth]. Extended abstract of candidate's thesis. Moskva: MPGU (Ru).

3. Kuznietsova 0. T. Ozdorovchi tekhnolohii u fizychnomu vykhovanni studentiv: teoriia, metodyka, praktyka [Health-improving technologies in physical education of students: theory, methodology, practice] [monohrafiia]. Rivne: Volyns区ki Oberehy, 2018. 416 p. (Ua).
4. Kuznietsova 0., Zubrytskyi B., Kosobutskyi Y., Sholopak P. Formuvannia zdoroviazberezhuvalnoi kompetentnosti maibutnikh fakhivtsiv v osvitnomu seredovyshchi vyshchoho navchalnoho zakladu [Formation of health-saving competence of future specialists in the educational environment of a higher educational establishment] [monohrafiia]. Opole: Akademiia upravlinnia ta administratsii. Opole, 2017. pp. 314-320; 380 p. (Ua).

5. Serhiienko L.P. Suchasnizasoby aktyvizatsii uchbovoho protsesu [Modern means of educational process activation]. Visnyk Tekhnolohichnoho universytetu Podillia: nauk. zhurnal. 2002; 5; Ch.3 (48): 32-35 (Ua).

6. Krutsevych T. Yu. Teoriia i metodyka fizychnoho vykhovannia [Theory and methods of physical education]: pidruchnyk dlia stud. vuziv fiz. vykhov. i sportu. T. 2. Metodyka fizychnoho vykhovannia riznykh hrup naselennia. Kyiv: Olimpiiska literatura; 2008. 368 p. (Ua).

7. Hryban, H. P. Fizychne vykhovannia studentiv ahrarnykh vyshchykh navchalnykh zakladiv [Physical education of students of agrarian higher educational institutions] [monohrafiia]. Zhytomyr: Ruta, 2012. 514 p. (Ua).

8. Ivashchenko L. Ya., N. P. Strapko Samostoyatel'ne zanyatiya fizicheskimi uprazhneniyami. [Independent physical exercise]. Kiev:Zdorov'e, 1988. 160 p. (Ru).

9. Mamychkin V. F., Zaytsev V. A., Varnakhin V. M. Nekotorye aspekty optimizatsii protsessa fizicheskogo vospitaniya v vuzakh [Some aspects of optimizing the process of physical education in universities]. Teoriya i praktika fizicheskoy kul'tury: nauch. zhurnal. 1996; 1: 23-24 (Ru).

10. Kuznietsova 0. T., Pinchuk V. F., Pasevych A. M., Kysil V. M. Ozdorovchi zasoby u profesiino-prykladnii fizychnii pidhotovtsi studentiv komunikatyvnoi hrupy spetsialnostei [Recreational activities in professional-applied physical training of communicative specialties students]. Metodychni rekomendatsii dlia studentiv dennoi formy navchannia z dystsypliny «Fizychne vykhovannia». Rivne: NUVHP, 2017. 33 p. (Ua).

11. Volkov L. V., Timchenko S. F. Metodika opredeleniya individual'nykh sposobnostey studentov pri vybore sportivnoy spetsializatsii [The method of determining the individual abilities of students when choosing a sports specialization]: uchebn. posobie. Kiev:Zdorov'e, 1990. 84 p. (Ru).

12. Vyatkin B., Lozhkin G. Integral'naya individual'nost' cheloveka v sportivnoy deyatel'nosti [Integral individuality of a person in sports activities] Nauka v olimpiyskom sporte: nauch. zhurnal. 2002; 1: 88-98 (Ru).

13. Ermakov V. A. (1984) Komulyativnyy effekt i ustoychivost'v proyavlenii fizicheskikh kachestv studentov pod vozdeystviem uprazhneniy raznoy napravlennosti [The cumulative effect and stability in the manifestation of the physical qualities of students under the influence of different directions exercises]. Extended abstract of candidate's thesis. Moskva: МИФКС (Ru).

14. Kryazh V. N. Osnovy differentsirovannogo komplektovaniya uchebnykh grupp. [Fundamentals of differentiated training groups formation]. Optimizatsiya fizicheskogo vospitaniya studentov i podgotovka sportsmenov v vuze: tez. dokl. nauch. - prakt. konf. Minsk, 1991. 1: $35-36$.

15. Malikov N., Sushchenko L., Bogdanovskaya N. Ispol'zovanie sovremennykh metodicheskikh podkhodov $\mathrm{k}$ otsenke fizicheskoy podgotovlennosti studentov [Usage of modern methodological approaches to student physical fitness assessment]. Fizichne vikhovannya, sport i kul'tura zdorov'ya u suchasnomu suspil'stvi : zb. nauk. prats'. Luts'k, 2005. 1:155-157 (Ru). 
16. Novitskiy Yu. V. (1997) Organizatsionno-metodicheskiy podkhod $v$ individualizatsii protsessa fizicheskogo vospitaniya studentov [Organizational and methodical approach to individualization of students physical education process]. Extended abstract of candidate's thesis. Kiev: NPU (Ru).

17. Serikov V. V. Obrazovanie i lichnost'. Teoriya i praktika proektirovaniya pedagogicheskikh sistem. [Education and personality. Theory and practice of designing educational systems]. Moskva: «Logos», 1999. 272 p. (Ru).

18. Zhamardiy V. O., Donchenko V. I., Yemets A. V., Skrinnik Y. 0. Physical development by means of fitness technologies as one of general aspects of student's health. Wiadomości Lekarskie. 2019; LXXII, 5, cz II: 10741078 (En).

The article is executed according to the theme of research work of the Department of pedagogical mastery and management named after I.A. Zyazun of the Poltava National Pedagogical University named after VG Korolenko: "Investigation of the content component of forming the foundations of pedagogical skill" (state registration number 0197U000065).

\section{ORCID and contributionship:}

Viktoriia I. Donchenko - 0000-0002-9665-7204 A,D,F

Valeriy O. Zhamardiy - 0000-0002-3579-6112 B,D,C,F

Olena M. Shkola - 0000-0003-3013-0423 E,F

Olena V. Kabatska - 0000-0001-7984-7391 E,F

Valerii H. Fomenko - 0000-0001-7656-269X E,F

\section{Conflict of interest:}

The Authors declare no conflict of interest

\section{CORRESPONDING AUTHOR Viktoriia I. Donchenko}

Department of Physical Education and Health, Physical Rehabilitation and Sports Medicine, Ukrainian Medical Stomatological Academy Shevchenko 23 str., 36011 Poltava, Ukraine tel: +380662674172

e-mail:vik.donchenko@gmail.com

Received: 13.05 .2019

Accepted:25.11.2019

A - Work concept and design, B - Data collection and analysis, C - Responsibility for statistical analysis,

D-Writing the article, $\mathbf{E}$-Critical review, $\mathbf{F}$ - Final approval of the article 